\title{
ANALISIS NILAI TUKAR PETANI PADA USAHATANI HORTIKULTURA DI KECAMATAN KAYANGAN KABUPATEN LOMBOK UTARA
}

\section{MARKETING ANALYSIS AND DEVELOPMENT STRATEGY OF THE KETAK WOVEN HANDICRAFT BUSINESS IN CENTRAL LOMBOK REGENCY}

\author{
Novila Alta Bening ${ }^{1}$, IGL Parta Tanaya ${ }^{2}$, Syarifuddin ${ }^{3}$ \\ ${ }^{1,2,3}$ Program Studi Agribisnis, Universitas Mataram, Kota Mataram, Indonesia. \\ *Email Penulis Korespondensi: novilaalta1996@gmail.com
}

\begin{abstract}
ABSTRAK
Tujuan penelitian ini adalah : (1) Untuk mengetahui Nilai Tukar Petani pada usahatani hortikultura di Kecamatan Kayangan Kabupaten Lombok Utara; (2) untuk mengetahui kendala-kendala yang dihadapi Petani pada Usahatani Hortikultura di Kecamatan Kayangan Kabupaten Lombok Utara. Penelitian ini menggunakan metode deskriptif, yang dilakukan di Kabupaten Lombok Utara yaitu di Kecamatan Kayangan tepatnya di Desa Pendua, Desa Kayangan, Desa Sesait, Desa Gumantar dan Desa Selengen yang ditetapkan secara "purposive sampling". Dalam penelitian ini jumlah responden ditentukan secara "quota sampling" dengan jumlah responden sebanyak 45 orang petani dan untuk penentuan responden secara "random sampling" yaitu didapatkan 8 petani di Desa Pendua, 13 petani di Desa Kayangan, 7 petani di Desa Sesait, 9 petani di Desa Gumantar dan 8 Petani di Desa Selengen. Hasil penelitian menunjukkan (1) Indeks harga yang diterima petani pada usahatani hortikultura di Kecamatan Kayangan Kabupaten Lombok Utara yaitu 142\% sedangkan untuk nilai indeks harga yang dibayarkan petani hortikultura di Kecamatan Kayangan Kabupaten Lombok Utara yaitu $105 \%$. Sehingga didapatkan nilai tukar petani pada usahatani hortikultura di Kecamatan Kayangan Kabupaten Lombok Utara yaitu $136 \%$. (2) Kendala yang dihadapi petani pada usahatani hortikultura di Kecamatan Kayangan Kabupaten Lombok Utara yaitu modal, harga, cuaca dan hama.

Kata kunci :nilai tukar petani, indeks harga yang diterima, indeks harga yang dibayar, petani hortikultura.
\end{abstract}

\begin{abstract}
The objectives of this study are: (1) To find the Farmers Exchange Rates in horticultural farming in Kayangan District, North Lombok Regency; (2) to find the obstacles faced by farmers in Horticultural Farming in Kayangan District, North Lombok Regency. This research uses descriptive method, which was carrie out in North Lombok Regency, name Kayangan District, precisely in Pendua Village, Kayangan Village, Sesait Village, Gumantar Village and Selengen Village which determine by "purposive sample". In this study the number of respondents was determine by "quota sample" with the number of respondents as many as 45 farmers and for the determina of respondents by "random sample" ie found 8 farmers in Pendua Village, 13 farmers in Kayangan Village, 7 farmers in Sesait Village, 9 farmers in Gumantar Village and 8 Farmers in Selengen Village. The results showed (1) the price index received by farmers in horticultural farming in Kayangan District of North Lombok Regency was $142 \%$ while for the price index value paid by horticultural farmers in Kayangan District of North Lombok Regency was 105\%. So we get the exchange rate of farmers in horticultural farming in Kayangan District, North Lombok Regency, which 136\%. (2) The constraints faced by farmers in horticultural farming in the District of Kayangan, North Lombok Regency are capital, price, weather and pests.

Keywords : farmer's term of trade, the price index received, the price index paid, horticultural farmers.
\end{abstract}

Bening, N.A., Tanaya, I.G.L.P., dan Syarifuddin 


\section{PENDAHULUAN}

Pembangunan pertanian di Indonesia telah memberikan sumbangan besar dalam keberhasilan pembangunan nasional, baik langsung maupun tidak langsung melalui penciptaan kondisi yang kondusif bagi pelaksanaan pembangunan dan hubungan sinergis dengan sektor lain (Riyadh, 2015). Pengenalan pembangunan pertanian kearah perbaikan kesejahteraan petani, akan sangat berguna untuk mengkaji dampak perkembangan yang dilaksanakan terhadap perbaikan kesejahteraan petani, agar dapat menjadi masukan untuk pelaksanaan pembangunan pertanian selanjutnya (Indraningsih, et al., 2003). Salah satu indikator yang digunakan untuk mengukur kesejahteraan petani adalah nilai tukar petani (NTP). NTP merupakan perbandingan antara indeks harga yang diterima petani (IT) dengan indeks harga yang dibayarkan petani (IB) (Nirmala et al, 2016). dengan kata lain NTP merupakan alat ukur kemampuan tukar barang-barang (produksi) pertanian yang dihasilkan oleh petani dengan barang atau jasa yang bisa didapatkan untuk konsumsi rumah tangga petani dan keperluan dalam memproduksi barang-barang pertanian (Hendayana, 2001). Simatupang dan Maulana (2008) menjelaskan NTP merupakan salah satu pilihan terbatas bagi peneliti yang mengamati pembangunan pertanian dalam mengukur tingkat kesejahteraan petani. Jika nilai NTP relatif tinggi maka petani dapat dikategorikan telah sejahtera, sebaliknya jika nilai NTP relatif rendah maka petani dapat dikategorikan belum sejahtera (Setiawan et al., 2019). Rumah tangga dengan pangsa pengeluaran pangan yang lebih tinggi tergolong rumah tangga dengan tingkat kesejahteraan relatif rendah dibandingkan dengan rumah tangga dengan proporsi pengeluaran untuk pangan yang rendah (Adriani et al, 2020).

Nusa Tenggara Barat memiliki prospek yang baik dalam sektor pertanian, dengan didukung kekayaan alam yang melimpah dan menyimpan keanekaragaman sumber daya alam. Potensi sumber daya alam yang di miliki salah satunya yaitu lahan pertanian. Keadaan sektor pertanian yang mendukung dapat mempengaruhi kesejahteraan masyarakat. Kesejahteraan masyarakat di NTB bisa dikatakan sejahtera apabila dilihat dari data NTP. Nilai NTP di Provinsi Nusa Tenggara Barat selalu mengalami peningkatan disetiap tahunnya. Salah satu komoditas yang dapat dikembangkan dalam rangka meningkatkan kesejahteraan masyarakat di NTB umumnya dan masyarakat di pedesaan khususnya adalah komoditas hortikultura (Tanaya et al, 2021). Komoditas hortikultura merupakan komoditas yang potensial untuk dikembangkan dalam sektor pertanian di daerah NTB (Septiadi \& Nursan, 2020). Sedikitnya hortikultura mempunyai dua peranan penting bagi Provinsi NTB, yaitu sebagai sumber pemenuhan gizi penduduk (septiadi \& Mundiyah, 2020), dan menjadi salah satu sub sektor yang dapat menghasilkan nilai tambah. Dalam hal pemenuhan gizi penduduk, hortikultura tidak hanya sebagai pelengkap, tetapi juga dimungkinkan sebagai pengganti (subtitusi) (BPS NTB, 2018).

Melihat hal yang demikian, petani di Kabupaten Lombok Utara khususnya Kecamatan Kayangan melalui bimbingan dan arahan dari penyuluh, banyak petani di Kecamatan Kayangan yang membudidayakan tanaman hortikultura tersebut. Produk hortikultura di Kecamatan Kayangan sudah dapat dinikmati hasilnya walaupun masih banyak diantaranya yang belum berhasil membudidayakan tanaman hortikultura tersebut.

Berdasarkan uraian diatas tersebut perlu untuk melihat bagaimana perkembangan nilai tukar petani tanaman hortikultura di Kecamatan Kayangan Kabupaten Lombok Utara dan kendala-kendala apa saja yang dihadapi petani pada usahatani hortikultura di Kecamatan

Bening, N.A., Tanaya, I.G.L.P., dan Syarifuddin 
Kayangan Kabupaten Lombok Utara. Sehingga perlu dilakukan penelitian tentang "Analisis Nilai Tukar Petani Pada Usahatani Hortikultura Di Kecamatan kayangan Kabupaten Lombok Utara”. Penelitian ini bertujuan untuk : (1) mengetahui nilai tukar petani pada usahatani hortikultura di Kecamatan Kayangan Kabupaten Lombok Utara, (2) mengetahui kendala-kendala yang dihadapi petani pada usahatani hortikultura di Kecamatan Kayangan Kabupaten Lombok Utara.

\section{METODE PENELITIAN}

Metode yang digunakan dalam penelitian ini adalah metode deskriptif. Unit analisis adalah petani hortikultura. Penelitian ini dilakukan pada 5 Desa dari 8 Desa di Kecamatan Kayangan Kabupaten Lombok Utara yaitu Desa Pendua, Desa Kayangan, Desa Sesait, Desa Gumantar dan Desa Selengen secara purposive sampling. Penentuan jumlah responden dilakukan secara quota sampling sebanyak 45 orang petani hortikultura yang masing-masing dipilih secara random sampling, yaitu Desa Pendua 8 orang, Desa Kayangan 13 orang, Desa Sesait 7, Desa Gumantar 9 orang orang, dan Desa Selengen 8 orang. Jenis data yang digunakan dalam penelitian ini adalah data kualitatif dan data kuantitatif. Sumber data dalam penelitian ini adalah sumber data primer dan data sekunder. Data dianalisis menggunakan analisis nilai tukar petani dan analisis regresi linear.

Untuk analisis Nilai Tukar Petani (NTP) digunakan rumus: (BPS, 2013).

Keterangan :

$$
N T P=\frac{I T}{I B} x 100
$$

NTP = Nilai Tukar Petani

IT = Indeks Harga yang Diterima Petani

IB = Indeks Harga yang Dibayar Petani

Untuk analisis Indeks Harga yang Diterima dan yang Dibayarkan menggunakan Formula Indeks Laspeyres yang dimodifikasi oleh BPS (1995):

$$
\text { In }=\frac{\sum_{i=1}^{m} \frac{P n i}{P(n-1) i} P(n-1) i . Q o i}{\sum_{i=1}^{m} \text { Poi.Qoi }} \times 100
$$

Keterangan :

In $\quad=$ Indeks harga bulanan bulan ke $\mathrm{n}$ (IT dan IB)

$\mathrm{P}_{\mathrm{ni}} \quad=$ Harga bulan ke $\mathrm{n}$ untuk jenis barang ke $\mathrm{i}$

$\mathrm{P}(\mathrm{n}-1) \quad=$ Harga bulan ke (n-1) untuk jenis barang ke $\mathrm{i}$

$\mathrm{P}_{\mathrm{ni}} / \mathrm{P}(\mathrm{n}-1) \quad=$ Relatif harga bulan ke $\mathrm{n}$ untuk jenis barang ke $\mathrm{i}$

$\mathrm{P}_{\mathrm{oi}} \quad=$ Harga dasar tahun dasar untuk jenis barang ke $\mathrm{i}$

Q $\quad=$ Quantitas pada tahun dasar untuk barang ke $\mathrm{i}$

$\mathrm{m} \quad$ = Banyaknya barang yang tercakup dalam paket komoditas

\section{HASIL DAN PEMBAHASAN}

\section{Perkembangan Nilai Tukar Petani}

\section{Perkembangan Harga Komoditi Yang Dihasilkan Responden}

Harga komoditi yang dihasilkan petani tanaman hortikultura merupakan harga transaksi antara petani dengan pembeli untuk setiap jenis barang atau jasa yang dihasilkan 
berdasarkan satuan tertentu. Berdasarkan hasil penelitian harga barang atau jasa yang dihasilkan petani mengalami perubahan yang positip. Secara rinci perkembangan harga komoditi yang dihasilkan dapat dilihat pada tabel 1.

Tabel 1. Perkembangan Rata-Rata Harga yang Dihasilkan Responden Pada Tahun 2017 dan Tahun 2018 di Kecamatan Kayangan Kabupaten Lombok Utara

\begin{tabular}{|c|c|c|c|c|c|c|}
\hline \multirow[b]{2}{*}{ No } & \multirow[b]{2}{*}{ Komoditi } & \multirow[b]{2}{*}{ Satuan $(\mathrm{Kg})$} & \multicolumn{2}{|c|}{ Harga (Rp) } & \multicolumn{2}{|c|}{ Perubahan } \\
\hline & & & 2017 & 2018 & $\begin{array}{l}\text { Harga } \\
\text { (Rp) }\end{array}$ & $\begin{array}{l}\text { Persentase } \\
(\%)\end{array}$ \\
\hline 1. & Cabai & 1,216 & 12,911 & 18,978 & 6,067 & 77.61 \\
\hline 2. & Tomat & 2,314 & 5,500 & 7,250 & 1,750 & 22.39 \\
\hline & umlah & 3,530 & 18,411 & 26,228 & 7,817 & 100 \\
\hline
\end{tabular}

Sumber : Data Primer diolah, (2019)

Dari tabel diatas dapat disimpulkan bahwa rata-rata harga cabai pada tahun 2018 mengalami kenaikan sebesar $77.61 \%$ dengan harga rata-rata 12,911 rupiah pada tahun 2017 dan 18,978 rupiah pada tahun 2018. Sedangkan untuk harga tomat pada tahun 2018 meningkat 22.39\% dari tahun 2017 dengan perubahan harga sebesar 1,750 rupiah.

Berdasarkan data pada tabel diatas menunjukkan bahwa harga output yang diterima oleh petani yang satu dan yang lainnya bervariasi untuk tanaman cabai pada tahun 2017 dengan kisaran harga Rp 7,000-/Kg sampai dengan Rp20,000-/Kg dengan harga ratarata $\mathrm{Rp} 12,622-/ \mathrm{Kg}$. Untuk tanaman tomat dengan kisaran harga $\mathrm{Rp} \mathrm{3,000-/Kg} \mathrm{sampai}$ dengan $\mathrm{Rp} \mathrm{10,000-/Kg} \mathrm{dengan} \mathrm{harga} \mathrm{rata-rata} \mathrm{Rp} \mathrm{5,500-/Kg.} \mathrm{Sedangkan} \mathrm{pada} \mathrm{tahun} 2018$ untuk tanaman cabai dengan kisaran harga $\mathrm{Rp} \mathrm{8,000-/Kg} \mathrm{sampai} \mathrm{dengan} \mathrm{Rp} \mathrm{50,000-/Kg}$

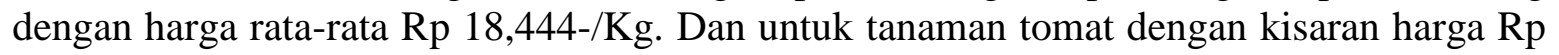
4,000-/Kg sampai dengan $\mathrm{Rp} 11,000-/ \mathrm{Kg}$ dengan harga rata-rata $\mathrm{Rp} 7,250-/ \mathrm{Kg}$. Ini menunjukkan bahwa harga outpun yang diterima petani pada tahun 2017 dan 2018 bervariasi tergantung dari kualitas produksinya.

\section{Perkembangan Harga Komoditi Yang Dibayarkan Responden}

Harga komoditi yang dibayarkan petani hortikultura adalah harga transaksi antara penjual dan pembeli (petani) untuk setiap jenis barang dan jasa yang dibayarkan petani hortikultura dengan tujuan untuk memenuhi kebutuhan konsumsi sendiri baik untuk konsumsi rumahtangga maupun untuk keperluan usahatani.

Pengeluaran rumahtangga petani hortikultura dibedakan menjadi pengeluaran makanan dan non makanan. Sumber bahan untuk makanan adalah dari hasil sendiri, pasar dan bahkan tetangga. Pengeluaran ini meliputi pengeluaran seperti beras, daging (ayam,sapi), ikan, minyak goreng, bahan minuman (kopi, gula, dan teh). Sementara untuk pengeluaran non makanan meliputi sandang (sabun, sikat gigi, pasta gigi), perumahan (listrik), Pendidikan (buku tulis, pensil, sepatu, seragam, tas), transportasi (bensin), keperluan usahatani ( bibit cabai, bibit tomat, pupuk dan pestisida), dan jasa ( upah tenaga kerja).

Tabel 2. Perkembangan Rata-rata Jumlah dan Harga Barang Konsumsi yang Dibayarkan Responden Tahun 2017 dan Tahun 2018 Di Kec. Kayangan, Kab. Lombok Utara

\begin{tabular}{llccccccr}
\hline \multirow{2}{*}{ No } & \multirow{2}{*}{$\begin{array}{c}\text { Yang } \\
\text { Dibayarkan }\end{array}$} & \multicolumn{2}{c}{ Jumlah } & \multicolumn{2}{c}{ Harga } & \multicolumn{2}{c}{ Perubahan } \\
\cline { 3 - 8 } & $\mathbf{2 0 1 7}$ & $\mathbf{2 0 1 8}$ & $\mathbf{2 0 1 7}$ & $\mathbf{2 0 1 8}$ & $\begin{array}{c}\text { Harga } \\
(\mathbf{R p})\end{array}$ & $\begin{array}{c}\text { Persentase } \\
(\mathbf{\%})\end{array}$ \\
\hline 1. & Beras & 228 & 208 & 10,000 & 10,000 & 0 & & 0
\end{tabular}

Bening, N.A., Tanaya, I.G.L.P., dan Syarifuddin 


\begin{tabular}{|c|c|c|c|c|c|c|c|}
\hline \multirow[b]{2}{*}{ No } & \multirow[b]{2}{*}{$\begin{array}{c}\text { Yang } \\
\text { Dibayarkan }\end{array}$} & \multicolumn{2}{|c|}{ Jumlah } & \multicolumn{2}{|c|}{ Harga } & \multicolumn{2}{|c|}{ Perubahan } \\
\hline & & 2017 & 2018 & 2017 & 2018 & $\begin{array}{l}\text { Harga } \\
\text { (Rp) }\end{array}$ & $\begin{array}{c}\text { Persentase } \\
(\%)\end{array}$ \\
\hline 2. & Ikan & 13 & 12 & 24,000 & 25,000 & 1,000 & 1.84 \\
\hline 3. & $\begin{array}{l}\text { Daging } \\
\text { sapi }\end{array}$ & 8 & 7 & 99,733 & 110,000 & 10,267 & 18.89 \\
\hline 4. & $\begin{array}{l}\text { Daging } \\
\text { Ayam }\end{array}$ & 5 & 5 & 30,822 & 35,000 & 4,178 & 7.69 \\
\hline 5. & Telur & 153 & 143 & 1,500 & 2,000 & 500 & 0.92 \\
\hline 6. & $\begin{array}{l}\text { Minyak } \\
\text { Goreng }\end{array}$ & 26 & 26 & 15,000 & 16,000 & 1,000 & 1.84 \\
\hline 7. & Gula & 22 & 21 & 12,500 & 13,000 & 500 & 0.92 \\
\hline 8. & Kopi & 6 & 6 & 24,000 & 25,000 & 1,000 & 1.84 \\
\hline 9. & The & 5 & 5 & 9,000 & 10,000 & 1,000 & 1.84 \\
\hline 10. & $\begin{array}{l}\text { Sabun } \\
\text { Mandi }\end{array}$ & 42 & 41 & 2,493 & 2,922 & 429 & 0.79 \\
\hline 11. & Pasta Gigi & 13 & 13 & 11,044 & 11,644 & 600 & 1.10 \\
\hline 12. & Sikat Gigi & 11 & 11 & 4,622 & 5,033 & 411 & 0.76 \\
\hline 13. & Pakaian & 2 & 2 & 84,667 & 65,667 & $(19,000)$ & $(34.95)$ \\
\hline 14. & Sepatu & 1 & 1 & 55,143 & 50,000 & $(5,143)$ & -9.46 \\
\hline 15. & Tas & 1 & 1 & 61,286 & 62,000 & 714 & 1.31 \\
\hline 16. & Alat Tulis & 13 & 13 & 2,500 & 3,000 & 500 & 0.92 \\
\hline 17. & Buku Tulis & 12 & 12 & 2,500 & 3,000 & 500 & 0.92 \\
\hline 18. & Listrik & 1 & 1 & 204,000 & 239,778 & 35,778 & 65.82 \\
\hline 19. & Air & 1 & 1 & 98,438 & 98,438 & 0 & 0 \\
\hline 20. & Bensin & 152 & 152 & 8,000 & 9,000 & 1,000 & 1.84 \\
\hline 21. & Pendidikan & 1 & 1 & 571,429 & 629,000 & 57,571 & 105.91 \\
\hline 22. & Kesehatan & 4 & 4 & 245,556 & 207,111 & $(38,444)$ & (70.72) \\
\hline & Jumlah & 720 & 685 & $1,578,232$ & $1,632,593$ & 54,361 & 100 \\
\hline
\end{tabular}

Sumber : Data Primer diolah, (2019)

Pada tabel diatas rata-rata jumlah kebutuhan barang konsumsi mengalami penurunan dari 720 pada tahun 2017 menjadi 685 pada tahun 2018. Penyebab penurunan konsumsi ini karena salah satunya bencana yang melanda Nusa Tenggara Barat pada tahun 2018. Keadaan yang tidak memungkinkan dan kurangnya ketersediaan bahan makanan membuat warga untuk berhemat dalam mengkonsumsi bahan makanan. Sedangkan untuk rata-rata harga yang dikeluarkan petani hortikultura meningkat dari tahun 2017 ke 2018 sebesar Rp. 54,361 .

Tabel 3. Perkembangan Rata-rata Jumlah dan Harga Keperluan Usahatani yang Dibayarkan Responden Tahun 2017 dan Tahun 2018 Di Kecamatan Kayangan kabupaten Lombok Utara

\begin{tabular}{lccccccc}
\hline \multirow{2}{*}{ No } & Yang & \multicolumn{2}{c}{ Jumlah } & \multicolumn{2}{c}{ Harga } & \multicolumn{2}{c}{ Perubahan } \\
\cline { 2 - 8 } & Dibayarkan & 2017 & 2018 & 2017 & 2018 & $\begin{array}{l}\text { Harga } \\
(\text { Rp })\end{array}$ & $\begin{array}{l}\text { Persentase } \\
(\%)\end{array}$ \\
\hline
\end{tabular}

1. Keperluan

Bening, N.A., Tanaya, I.G.L.P., dan Syarifuddin 


\begin{tabular}{llrrrrrr}
\hline \multirow{2}{*}{ No } & $\begin{array}{l}\text { Yang } \\
\text { Dibayarkan }\end{array}$ & \multicolumn{2}{c}{ Jumlah } & \multicolumn{2}{c}{ Harga } & \multicolumn{2}{c}{ Perubahan } \\
\cline { 2 - 8 } & $\mathbf{2 0 1 7}$ & $\mathbf{2 0 1 8}$ & $\mathbf{2 0 1 7}$ & $\mathbf{2 0 1 8}$ & $\begin{array}{l}\text { Harga } \\
(\mathbf{R p})\end{array}$ & $\begin{array}{l}\text { Persentase } \\
(\mathbf{\%})\end{array}$ \\
\hline a. & Bibit & & & & & & \\
1. Cabai & 2,978 & 2,978 & 290 & 322 & 32 & 0.17 \\
2. Tomat & 2,326 & 2,326 & 297 & 332 & 34 & 0.19 \\
b. Pupuk & & & & & & \\
1. NPK & 84 & 84 & 4,249 & 4,667 & 418 & 2.26 \\
2. KNO & 7 & 7 & 11,500 & 12,000 & 500 & 2.71 \\
3. Organik & 1,180 & 1,180 & 450 & 500 & 50 & 0.27 \\
4. Kalsium & 2 & 2 & 14,500 & 15,000 & 500 & 2.71 \\
5. Jimi Hantu & 1 & 1 & 147,000 & 150,000 & 3,000 & 16.24 \\
c. Obat & & & & & & \\
1. Bio M & 1 & 1 & 105,000 & 110,000 & 5,000 & 27.06 \\
2. Comfidor & 2 & 2 & 27,167 & 28,542 & 1,375 & 7.44 \\
3. Sidakron & 16 & 16 & 74,864 & 77,273 & 2,409 & 13.04 \\
4. Antracol & 1 & 1 & 123,400 & 126,769 & 3,369 & 18.23 \\
5. Demolish & 179 & 179 & 159,263 & 161,053 & 1,789 & 9.68 \\
\hline Jumlah & 6,778 & 6,778 & 667,980 & 686,457 & 18,477 & 100 \\
\hline
\end{tabular}

Sumber : Data Primer diolah, (2019)

Pada tabel diatas menunjukkan bahwa rata-rata jumlah keperluan usahatani yang digunakan oleh petani hortikultura di Kecamatan Kayangan Kabupaten Lombok Utara tidak mengalami perubahan. Hal ini disebabkan luas lahan yang diusahakan petani hortikultura di Kecamatan Kayangan pada tahun 2017 dan 2018 sama. Sedangkan rata-rata harga yang dibayarkan untuk keperluan usahatani pada tahun 2018 mengalami kenaikan dibandingkan dengan harga yang dibayarkan pada tahun 2017 yaitu sebesar Rp 18.477. Kenaikan harga keperluan usahatani ini disebabkan karena kurangnya ketersediaan pupuk, sehingga distributor menaikkan harga dipasaran.

Tabel 4. Perkembangan Rata-rata Jumlah dan Harga Jasa yang Dibayarkan Responden Tahun 2017 dan Tahun 2018 Di Kecamatan Kayangan kabupaten Lombok Utara

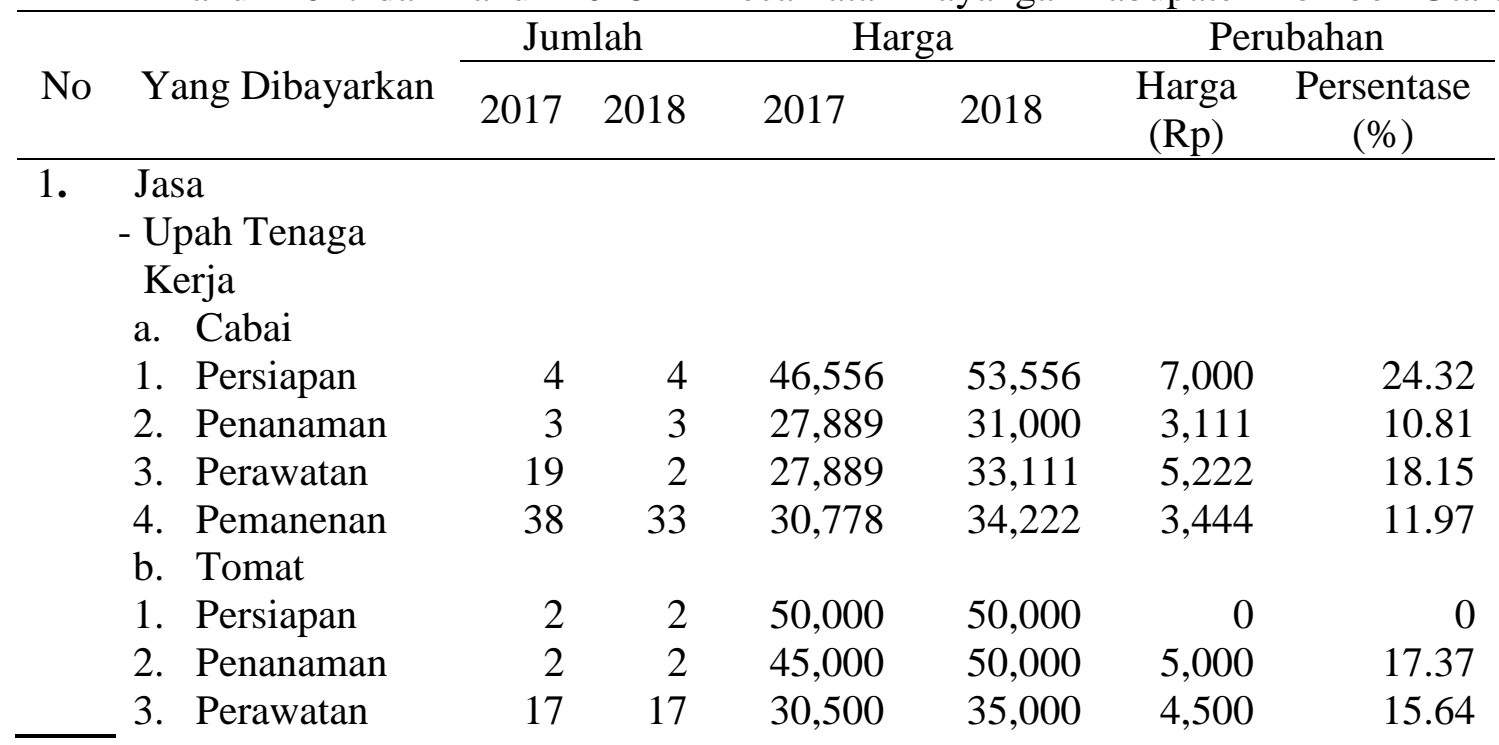

Bening, N.A., Tanaya, I.G.L.P., dan Syarifuddin 


\begin{tabular}{crrrrrr}
\hline 4. Pemanenan & 23 & 26 & 25,250 & 25,750 & 500 & 1.74 \\
\hline Jumlah & 107 & 89 & 283,861 & 312,639 & 28,778 & 100 \\
\hline
\end{tabular}

Sumber : Data Primer diolah, (2019)

Berdasarkan tabel diatas menunjukkan bahwa jumlah yang dibayarkan petani hortikultura pada tahun 2017 yaitu 107 hari kerja, sedangkan pada tahun 2018 yaitu 89 hari kerja. Penurunan jumlah hari kerja di tahun 2018 disebabkan karena bencana gempa yang melanda Nusa Tenggara Barat. Untuk rata-rata harga yang dibayarkan oleh petani hortikultura untuk jasa yaitu Rp.283.861 pada tahun 2017 dan mengalami kenaikan pada tahun 2018 sebesar Rp.28.778. sehingga harga yang dibayarkan petani pada tahun 2018 sebesar Rp.312.639. Besar kecilnya pengeluaran petani hortikultura tergantung dari jumlah anggota keluarga dan luas lahan garapan.

\section{Indeks Harga Yang Diterima Petani}

Indeks harga yang diterima petani adalah indeks harga yang menunjukkan perkembangan harga komoditi yang dihasilkan petani. Harga yang diterima merupakan rata-rata harga produsen dari hasil produksi sebelum ditambah biaya transportasi dan biaya lainnya dalam satu periode. Dengan kata lain harga yang diterima merupakan penerimaan responden dari hasil usahanya. Dilihat dari segi ekonomi pertanian, harga yang diterima responden merupakan faktor yang mempengaruhi prilaku dan kehidupan responden.

Berdasarkan hasil penelitian, penerimaan responden berasal dari usahatani yang diilakukan oleh responden. Secara rinci rata-rata penerimaan responden pada tahun 2017 dan 2018 di Kecamatan Kayangan dapat dilihat pada tabel 5.

Tabel 5. Rata-rata penerimaan responden pada tahun 2017 dan 2018 di Kecamatan Kayangan.

\begin{tabular}{lcrr}
\hline No & Komoditi & Jumlah $(\mathrm{Rp})$ & Persentase $(\%)$ \\
\hline 1. & Cabai & $21,308,556$ & 59.918 \\
2. & Tomat & $14,254,500$ & 40.082 \\
\hline & Jumlah & $35,563,056$ & 100 \\
\hline
\end{tabular}

Sumber : Data Primer diolah, (2019)

Dari tabel 4.17 dapat dilihat bahwa penerimaan petani untuk usahatani cabai yaitu sebesar 59.92\% ( $R p$ 21,308,556), sedangkan untuk usahatani tomat menyumbang penerimaan sebesar Rp 14,254,500 atau sebesar $40.082 \%$. Perbedaan penerimaan antara tanaman cabai dan tanaman tomat ini didasarkan pada harga pasaran bahwa harga cabai lebih tinggi dari harga tomat. Untuk biaya mulai dari penanaman sampai panen tanaman cabai memang lebih banyak menghabiskan biaya dibandingkan dengan tanaman tomat, sehingga input yang didapatkan dari tanaman cabai lebih besar daripada tanaman tomat. Selain itu para petani di Kecamatan Kayangan lebih banyak membudidayakan tanaman cabai di area lahan yang lebih besar dibandingkan dengan budidaya tanaman tomat.

Berdasarkan penerimaan yang diterima responden maka diperoleh nilai indeks yang diterima sebesar $142 \%$. Dari angka indeks yang diterima dapat dilihat bahwa harga komoditi yang dihasilkan dan indeks harga yang diterima petani pada tahun 2018 mengalami peningkatan dari tahun 2017. 


\section{Indeks Harga Yang Dibayar Petani}

Indeks harga yang dibayar merupakan indeks harga yang menunjukkan perkembangan harga kebutuhan rumahtangga baik untuk keperluan konsumsi dan untuk keperluan usaha. Harga yang dibayar responden adalah rata-rata harga barang atau jasa yang dikonsumsi atau dibeli baik untuk memenuhi kebutuhan rumahtangga ataupun untuk keperluan biaya produksi usahatani. Dengan kata lain harga yang dibayarkan merupakan biaya yang dikeluarkan petani responden untuk memenuhi kebutuhan rumahtangganya maupun untuk memenuhi keperluan biaya produksi pertanian. Untuk lebih jelas rata-rata pengeluaran responden pada tahun 2017 dan 2018 dapat dilihat pada tabel 6.

Tabel 6. Rata-rata Pengeluaran Responden pada Tahun 2017 dan Tahun 2018 di Kecamatan Kayangan.

\begin{tabular}{|c|c|c|c|}
\hline No & Barang dan Jasa & Jumlah (Rp/thn) & Persentase $(\%)$ \\
\hline 1. & Beras & $2,275,556$ & 8.16 \\
\hline 2. & Ikan & 336,111 & 1.21 \\
\hline 3. & Daging sapi & 831,111 & 2.98 \\
\hline 4. & Daging Ayam & 189,778 & 0.68 \\
\hline 5. & Telur & 305,333 & 1.09 \\
\hline 6. & Minyak Goreng & 418,133 & 1.50 \\
\hline 7. & Gula & 287,733 & 1.03 \\
\hline 8. & Kopi & 144,444 & 0.52 \\
\hline 9. & Teh & 50,000 & 0.18 \\
\hline 10. & Sabun Mandi & 121,333 & 0.44 \\
\hline 11. & Pasta Gigi & 149,689 & 0.54 \\
\hline 12. & Sikat Gigi & 56,489 & 0.20 \\
\hline 13. & Pakaian & 103,000 & 0.37 \\
\hline 14. & Sepatu & 70,286 & 0.25 \\
\hline 15. & Tas & 85,571 & 0.31 \\
\hline 16. & Alat Tulis & 38,057 & 0.1 \\
\hline 17. & Buku Tulis & 36,000 & 0.13 \\
\hline 18. & Listrik & 239,778 & 0.86 \\
\hline 19. & Air & 98,438 & 0.35 \\
\hline 20. & Bensin & $1,368,000$ & 4.90 \\
\hline 21. & Pendidikan & 632,857 & 2.27 \\
\hline 22. & Kesehatan & 784,000 & 2.81 \\
\hline 23. & Keperluan Usahatani & $15,745,256$ & 56.45 \\
\hline 24. & Jasa & $3,523,344$ & 12.63 \\
\hline & Jumlah & $27,890,297$ & 100 \\
\hline
\end{tabular}

Sumber : Data Primer diolah, (2019)

Dari tabel diatas dapat dilihat bahwa rata-rata pengeluaran responden dengan jumlah Rp. 27,890,297. Secara keseluruhan pengeluaran responden tertinggi dikeluarkan untuk keperluan usahatani sebesar 56.45\% (Rp 15,745,256). Hal ini disebabkan karena keperluan usahatani mencangkup upah tenagakerja, pembelian pupuk, bibit, dan obat-obatan yang sangat dibutuhkan untuk menunjang kelancaran usahatani responden. Harga terendah yang dibayarkan untuk kebutuhan sandang sebesar 2\% (Rp.660,425). Hal ini disebabkan karena besarnya pengeluaran untuk sandang tergantung dari jumlah anggota keluarga masing- 
masing responden. Berdasarkan pengeluaran yang dikeluarkan responden diperoleh angka indeks harga yang dibayarkan yaitu sebesar 105\%. Artinya indeks harga yang dibayarkan petani pada tahun 2018 mengalami peningkatan daripada indeks harga yang dibayarkan pada tahun 2017.

\section{Nilai Tukar Tanaman Hortikultura di Kecamatan Kayangan Kab. Lombok Utara}

Salah satu indikator yang digunakan untuk mengukur tingkat kesejahteraan petani adalah nilai tukar petani. Nilai tukar petani merupakan rasio antara indeks nilai yang diterima petani dengan indeks harga yang di bayarkan petani di nyatakan dalam persentase. Indeks harga yang diterima petani (IT) diperoleh dari hasil usahatani yang diusahakan oleh petani responden, sedangkan untuk indeks nilai yang dikeluarkan petani (IB) diperoleh dari biaya pengeluaran petani untuk memenuhi kebutuhan rumahtangga dan untuk biaya produksi pertanian.

Berdasarkan hasil penelitian, rata-rata indeks harga yang diterima responden adalah sebesar $142 \%$, sedangkan rata-rata indeks harga yang dibayarkan petani responden sebesar $105 \%$, sehingga diperoleh nilai tukar petani sebesar 136\%. Untuk lebih jelasnya rata-rata indeks harga yang diterima petani, indeks harga yang dibayarkan petani dan nilai tukar petani dapat dilihat pada tabel 4.19

Tabel 7. Rata-rata indeks harga yang diterima petani, indeks harga yang dibayarkan petani dan nilai tukar petani di Kecamatan Kayangan Kabupaten Lombok Utara

\begin{tabular}{llc}
\hline No & \multicolumn{1}{c}{ Uraian } & Persentase \\
\hline 1. & Indeks Harga Yang Diterima & 142 \\
2. & Indeks Harga Yang Dibayarkan & 104 \\
3. & Nilai Tukar Petani & 136 \\
\hline
\end{tabular}

Sumber: Data Primer diolah, (2019)

Dari tabel diatas dapat dilihat bahwa nilai tukar petani hortikultura pada tahun 2018 sebesar 136\%. Arti dari nilai NTP 136 yaitu dengan pengeluarkan (output) 100 rupiah maka didapatkan (input) sebesar 136 rupiah. Karna nilai tukar petani tahun $2018<100 \%$ maka dapat diartikan bahwa petani tanaman hortikultura di Kecamatan Kayangan Kabupaten Lombok Utara dalam kondisi sejahtera. Hal ini dikarenakan kenaikan harga produksi lebih besar dari kenaikan harga konsumsi rumahtangga.

Apabila dibandingkan dengan penelitian terdahulu yang dilakukan oleh (Fajri et al, 2016) yang memberikan hasil pada penelitiannya yaitu nilai tukar petani pada komoditas padi di Kabupaten Sragen memiliki nilai sebesar $175,28 \%$ yang artinya petani tersebut mendapatkan surplus dari usahatani padinya.

Secara umum menurunnya nilai tukar petani tanaman hortikultura di Kecamatan Kayangan Kabupaten Lombok Utara disebabkan oleh peningkatan harga komoditi yang dibayarkan responden lebih tinggi dibandingkan dengan peningkatan harga komoditi yang diterima responden. Disamping itu indeks harga yang diterima petani terbatas hanya pada komoditi hortikultura yaitu tomat dan cabai. Untuk harga yang dibayarkan pengeluaran tertinggi dikeluarkan untuk biaya usahatani. Pengeluaran petani untuk biaya usahatani adalah sebesar Rp.15,745,256 (56.45\%). 
Kendala yang dihadapi Petani Pada Usahatani Hortikultura di Kecamatan Kayangan

Tabel 8. Kendala-kendala yang dihadapi petani hortikultura di Kecamatan Kayangan

\begin{tabular}{ccccc}
\hline No. & Jenis Kendala & Ya (orang) & Tidak (orang) & Jumlah \\
\hline 1 & Modal & 5 & 40 & 45 \\
2 & Harga & 37 & 8 & 45 \\
3 & Cuaca & 37 & 8 & 45 \\
4 & Hama & 39 & 6 & 45 \\
5 & Modal \& Harga & 5 & 40 & 45 \\
6 & Modal \& Cuaca & 4 & 41 & 45 \\
7 & Modal \& Hama & 5 & 40 & 45 \\
8 & Harga \& Cuaca & 33 & 12 & 45 \\
9 & Harga \& Hama & 33 & 12 & 45 \\
10 & Cuaca \& Hama & 36 & 9 & 45 \\
\hline
\end{tabular}

Sumber: Data Primer diolah, (2019)

Dari tabel diatas dapat dilihat bahwa kendala yang dihadapi petani pada usahatani hortikultura di Kecamatan kayangan kabupaten Lombok Utara yaitu kendala modal, harga, cuaca dan hama. Kendala modal yang dimaksud adalah modal petani untuk membeli keperluan sarana produksi seperti pupuk, mulsa, pestisida, membayar tenaga kerja dan lainlain. Dari 45 responden didapatkan 5 petani terkendala modal dan sebanyak 40 petani mengatakan tidak terkendala modal.

Kendala harga yang dimaksud yaitu harga dari tanaman hortikultura yang cepat berubah-ubah dan tidak adanya kepastian harga disetiap musimnya. Hal ini dapat disebabkan karena tidak stabilnya stok dan kurangnya pengaturan pola tanam sehingga terjadi kelebihan produksi yang menyebabkan harga anjlok. Dari 45 responden 37 petani mengatakan ya dan sebanyak 8 petani mengatakan tidak mengalami kendala. Kendala cuaca yang dimaksud yaitu perubahan cuaca yang susah diprediksi. Pada musim kemarau seringkali hujan turun dengan intensitas yang cukup tinggi begitu sebaliknya, sehingga banyak tanaman yang rusak. Dari 45 responden 37 petani mengeluhkan dampak dari perubahan cuaca yang tidak menentu dan 8 petani mengatakan tidak.

Kendala hama yang dimaksud bukan lagi pada pengendaliannya, karena kebanyakan petani sudah faham Teknik mengendalikannya. Namun sekarang lebih pada perubahan perilaku (resistens dan mutase) dan siklus hama penyakit yang cenderung lebih cepat. Hal ini terjadi karena penggunaan pestisida yang tidak tepat dan berlebihan. Dari 45 responden 39 petani mengatakan ya dan 6 petani mengatakan tidak. Selain itu ada beberapa kombinasi kendala yang dihadapi oleh para petani diantaranya yaitu kendala modal \& harga, kendala modal \& cuaca, kendala modal \& hama, kendala harga \& cuaca, kendala harga \& hama serta ada kombinasi kendala cuaca\& hama.

Untuk kombinasi kendala modal \& harga ada 5 petani yang terkendala dan 40 petani tidak terkendala. Kendala modal \& cuaca ada 4 petani terkendala dan 41 petani tidak terkendala. Kendala modal \& hama ada 5 petani yang terkendala dan 40 petani tidak terkendala. Kendala harga \& cuaca ada 33 petani mengalami kendala dan 12 petani tidak terkendala. Untuk kendala harga \& hama ada 33 petani terkendala dan 12 petani tidak terkendala. Sedangkan untuk kendala cuaca dan hama ada 36 petani yang terkendala dan 9 petani tidak mengalami kendala. 


\section{KESIMPULAN DAN SARAN}

\section{Kesimpulan}

Berdasarkan hasil penelitian, analisis, dan pembahasan maka dapat ditarik kesimpulan sebagai berikut :

1. Indeks harga yang diterima petani pada usahatani hortikultura di Kecamatan Kayangan Kabupaten Lombok Utara yaitu $142 \%$ sedangkan untuk nilai indeks harga yang dibayarkan petani hortikultura di Kecamatan Kayangan Kabupaten Lombok Utara yaitu $104 \%$. Sehingga didapatkan nilai tukar petani pada usahatani hortikultura di Kecamatan Kayangan Kabupaten Lombok Utara yaitu $136 \%$.

2. Kendala yang dihadapi petani pada usahatani hortikultura di Kecamatan Kayangan Kabupaten Lombok Utara yaitu modal, harga, cuaca dan hama.

\section{Saran}

Berdasarkan penelitian yang telah dilaksanakan pada usahatani hortikultura di Kecamatan Kayangan Kabupaten Lombok Utara, maka dapat diajukan saran sebagai berikut :

1. Bagi pemerintah diharapkan memberikan perhatian/memperhitungkan faktor internal seperti sistem usahatani terkait pada keputusan petani dalam permodalan yang terkait penggunaan saprodi yang juga mempengaruhi nilai tukar petani hortikultura selain faktor eksternal.

2. Bagi lembaga penyuluh untuk lebih memperhatikan para petani binaan dengan memberikan penyuluhan secara intens dari awal sampai pasca panen, sehingga kegagalan dalam panen dapat diminimalisir.

3. Bagi petani disarankan untuk meningkatkan kualitas produk dengan memperhatikan kualitas bibit yang digunakan dan kualitas pupuk sehingga menghasilkan produk hortikultura yang berkualitas dan memiliki harga jual yang tinggi.

\section{DAFTAR PUSTAKA}

Adriani, E., Hasminidiarty, H., \& Fahmi, A. (2020). Nilai Tukar Petani Dan Pola Konsumsi Rumah Tangga (Studi Kasus: Petani Tanaman Pangan Dan Hortikultura Di Kecamatan Sabak Timur Kabupaten Tanjung Jabung Timur). J-MAS (Jurnal Manajemen Dan Sains), 5(1), 77-87.

Badan Pusat Statistik. (2018). Nusa Tenggara Barat Dalam Angka 2018. Badan Pusat Statistik Nusa Tenggara Barat. Mataram.

Fajri, M. R., Marwanti, S., \& Rahayu, W. (2016). Analisis Faktor Faktor yang Mempengaruhi Nilai Tukar Petani Sebagai Indikator Kesejahteraan Petani Padi Di Kabupaten Sragen. Agrista, 4, 85-94.

Hendayana, R. (2001). Analisis Faktor-Faktor Yang Mempengaruhi Nilai Tukar Petani. Pusat Penelitian dan Pengembangan Sosial Ekonomi Pertanian. Badan Penelitian dan Pengembangan Pertanian. Bogor.

Indraningsih, KS. Supriyati. M. Rahmat. (2000). Studi Nilai Tukar Petani dan Nilai Tukar Komoditas Pertanian. Laporan Hasil Penelitian. Pusat Penelitian Sosial Ekonomi Pertanian. Departemen Pertanian. Bogor.

Bening, N.A., Tanaya, I.G.L.P., dan Syarifuddin 
Nirmala, A. R., Hanani, N., \& Muhaimin, A. W. (2016). Analisis faktor faktor yang mempengaruhi nilai tukar petani tanaman pangan di Kabupaten Jombang. Habitat, 27(2), 66-71.

Riyadh, M. I. (2015). Analisis Nilai Tukar Petani Komoditas Tanaman Pangan di Sumatera Utara. Jurnal Ekonomi \& Kebijakan Publik, 6(1), 17-32.

Septiadi, D., \& Nursan, M. (2020). Optimasi Produksi Usaha Tani Sebagai Upaya Peningkatan Pendapatan Petani Sayuran Di Kota Mataram. Agrifo: Jurnal Agribisnis Universitas Malikussaleh, 5(2), 87-96.

Septiadi, D., \& Mundiyah, A. I. (2020). Strategi Pengembangan Usaha Tani Sayuran Berbasis Pertanian Organik. Agrifo: Jurnal Agribisnis Universitas Malikussaleh, 5(1), 35-43.

Setiawan, R. A. P., Noor, T. I., Sulistyowati, L., \& Setiawan, I. (2019). Analisis Tingkat Kesejahteraan Petani Kedelai Dengan Menggunakan Pendekatan Nilai Tukar Petani (Ntp) Dan Nilai Tukar Pendapatan Rumah Tangga Petani (Ntprp). Jurnal Agribisnis Terpadu, 12(2), 178-189.

Simatupang dan Maulana. (2008). Kaji Ulang Konsep dan Pengembangan Nilai Tukar Petani 2003-2006. Jurnal Ekonomi dan Pembangunan. LIPI.

Tanaya, I. G. L. P., Rosmilawati, R., Hidayati, A., \& Septiadi, D. (2021). Analisis Risiko Produksi Spesialisasi Tanaman Hortikultura di Kabupaten Lombok Utara (Analysis of the Risk of Production for Horticultural Specialties in North Lombok Regency). Prosiding SAINTEK, 3, 315-327. 